Article

\title{
Assessing the Sustainable Development of Micro-Hydro Power Plants in an Isolated Traditional Village West Java, Indonesia
}

\author{
Muhamad Alhaqurahman Isa ${ }^{1, *}$, Priana Sudjono ${ }^{1}$, Tatsuro Sato ${ }^{2}{ }^{(0)}$, Nariaki Onda ${ }^{3}{ }^{\mathbb{C}}$, Izuki Endo ${ }^{4}$, \\ Asari Takada ${ }^{5}$, Barti Setiani Muntalif ${ }^{1}$ and Jun'ichiro Ide ${ }^{6}(\mathbb{C}$
}

1 Department of Environmental Engineering, Bandung Institute of Technology, Bandung 40132, Indonesia; priana.sudjono@gmail.com (P.S.); barti_setiani@yahoo.com (B.S.M.)

2 Faculty of Architecture and Civil Engineering, Kyushu Sangyo University 2-3-1 Matsukadai, Higashi-ku, Fukuoka 813-8503, Japan; sato@ip.kyusan-u.ac.jp

3 Tohoku Research Center, Forestry and Forest Products Research Institute, Forest Research and Management Organization, 92-25 Shimokuriyagawa, Morioka 020-0123, Japan; ondanariaki@ffpri.affrc.go.jp

4 School of Human Science and Environment, University of Hyogo, 1-1-12 Shinzaike-Honcho, Himeji 670-0092, Japan; tkyizukifuk@gmail.com

5 Division of Hydrolic and Hydrologic Engineering, Institute for Rural Engineering, National Agriculture and Food Research Organization, 2-1-6 Kannondai, Tsukuba 305-8517, Japan; asari62069@gmail.com

6 Department of Applied Chemistry and Bioscience, Chitose Institute of Science and Technology, 758-65 Bibi, Chitose 066-8655, Japan; ide.junichiro@gmail.com

* Correspondence: haqi.isa@gmail.com

check for

updates

Citation: Isa, M.A.; Sudjono, P.; Sato,

T.; Onda, N.; Endo, I.; Takada, A.;

Muntalif, B.S.; Ide, J. Assessing the

Sustainable Development of

Micro-Hydro Power Plants in an Isolated Traditional Village West Java, Indonesia. Energies 2021, 14, 6456. https://doi.org/10.3390/en14206456

Academic Editor:

Dimitrios Katsaprakakis

Received: 20 July 2021

Accepted: 4 October 2021

Published: 9 October 2021

Publisher's Note: MDPI stays neutral with regard to jurisdictional claims in published maps and institutional affiliations.

Copyright: (c) 2021 by the authors. Licensee MDPI, Basel, Switzerland. This article is an open access article distributed under the terms and conditions of the Creative Commons Attribution (CC BY) license (https:/ / creativecommons.org/licenses/by/ $4.0 /)$.

\begin{abstract}
The sustainable development of micro-hydropower (MHP) plants is a challenge for rural electrification in developing countries, especially in Indonesia, which has diverse ethnic groups, cultures, and traditions in several isolated locations due to its complex terrain. The uniqueness of a social situation in a location can affect the sustainable electrification development. This study aimed to assess the sustainable development of MHP plants in the Kasepuhan Ciptagelar, which has unique traditions and cultural characteristics. The assessment was conducted using the sustainable development indicator (SDI) method, the Ilskog method, which can include social, economic, environmental, technical, and institutional dimensions. Data were collected through field investigations and qualitative dialogs to understand the culture and ways of thinking. The results of the Ilskog method analysis revealed that the environmental dimensions had the highest scores, whereas economic dimensions had the lowest scores, indicating that the cultural background of the Kasepuhan Ciptagelar impacted the SDI scores. This was attributable to the decision of Kasepuhan's traditional leader, which strengthened the community commitment to renewable energy use. However, the cultural background adversely impacted monetary income to sustain MHP plants. This study proposed that community innovation and microcredit availability could improve productive activities, resulting in better economic conditions to sustain MHP plants.
\end{abstract}

Keywords: sustainable development; traditional village; electrification; micro-hydropower; rural; sustainability indicator

\section{Introduction}

One of the most important renewable energy technologies for rural electrification in developing countries is micro-hydropower (MHP) generation [1], especially in mountainous areas with adequate water supply [2]. This is because MHP generation is environmentally friendly and inexpensive; it provides the best economic choice and is of great importance for the sustainable future [3,4]. Indonesia has enormous renewable hydropower energy potential, reaching $75 \mathrm{GW}$ [5], and approximately 19,385 MW can be developed into miniand micro-hydro plants [6]. Considering its potential and favorable geographical position, MHP may be the best choice for priority development in Indonesia. 
Micro-hydropower is an environmentally friendly power plant, but it can negatively impact society and the environment for larger capacities such as small hydro to hydropower. A hydropower construction has serious social and ecological impacts [7], including reducing sediment transport and severe alteration in river hydrology [8,9]. Wang et al. [10] showed that 236 small hydropower plants impacted river connectivity to some extent, leading to a range of environmental problems. Many countries have applied MHP. However, the classification of hydropower depends on each country's circumstances [11]. Some countries such as the USA, India, and Brazil classify MHP as a power plant with a capacity below $100 \mathrm{~kW}$ [12]. MHP is a run-of-river power plant, therefore, it does not need a reservoir that can limit the emergence of social and environmental impacts because the river is not converted into a lake, and the shape of the flow is not changed [11]. With minimal social and environmental impacts, this power plant is preferred to be developed, especially in remote areas.

Many MHP plants have been installed and distributed around rural areas of Indonesia, where some locations have a specific situation, such as villages with unique cultural characteristics. However, it has been reported that many MHP plants (MHPPs) have stopped functioning in rural areas due to failures caused by natural disasters and human errors [13]. However, their sustainability performance has not been well documented, and the relationship between rural conditions and sustainability is still not well understood. Very few studies have been conducted on sustainability issues, especially those related to social and cultural situations. Purwanto and Afifah [14] studied the impact of technosocioeconomic factors on sustainability in Indonesia; they concluded that economic factors performed negatively and positively in various dimensions, including the social, technical, environmental, and institutional dimensions. The results of an independent survey by the Ministry of Energy and Mineral Resources on MHP development in remote areas from 2011 to 2016 show that as many as $14 \%$ of the 65 MHPPs have suffered damage, generally due to issues related to social, technical, and environmental factors [15]. Sustainability assessments of MHPPs need to be conducted to comprehensively understand sustainability issues, especially in remote locations.

There are several alternative methodologies for evaluating the sustainability of electrification projects in rural areas, such as indicator-based analysis, the optimization technique, the multi-criteria decision-making (MCDM) method, system analysis approach [16], and the key performance indicator (KPI) approach $[17,18]$. The United Nations [19] has suggested sustainability indicators, which were explicitly introduced with stakeholder involvement consistent with the participatory process [16]. Previous researchers have applied sustainability indicators in their studies $[14,20]$. Compared to other methods, the advantages of the sustainability indicator method are to convey information and better understand a development project [21]. It can provide a solid basis for decision making at all levels [18]. However, few studies have applied this method to the assessment of rural electrification in remote villages with unique traditions and cultures.

MHPPs will continue to be developed in Indonesia consistent with the government's target to increase the renewable energy share. However, achieving sustainable development remains challenging, especially for MHPPs located in remote locations.

This study assessed the sustainability of two MHPPs in a remote village with unique cultural characteristics in West Java, Indonesia, where people live under distinct local traditions using a sustainable indicator framework. This study provides insight into how a village with substantial traditional factors can sustain its electrification under renewable energy technology.

\section{Materials and Methods}

\subsection{Site Description}

The study area is Kasepuhan Ciptagelar, located in Sinaresmi Village, Cisolok District, Sukabumi, Indonesia $\left(6^{\circ} 48^{\prime} \mathrm{S}, 106^{\circ} 29^{\prime} \mathrm{E}, 1121\right.$ m.a.s.l.). Figure 1 shows the Sukabumi district and the study area. Due to its location in the mountainous region, access is challenging, 
especially during the rainy season. Kasepuhan Ciptagelar is a home of the Sundanese indigenous people and was originally part of the Padjajaran-Bogor kingdom and was founded in 1937. The people of Kasepuhan live in 568 hamlets, primarily located in three districts: Lebak, Bogor, and Sukabumi. In addition to these three districts, some people of Kasepuhan also live and work in other areas outside of West Java and Banten, and even outside Java. They still identify themselves as members of the Kasepuhan community.

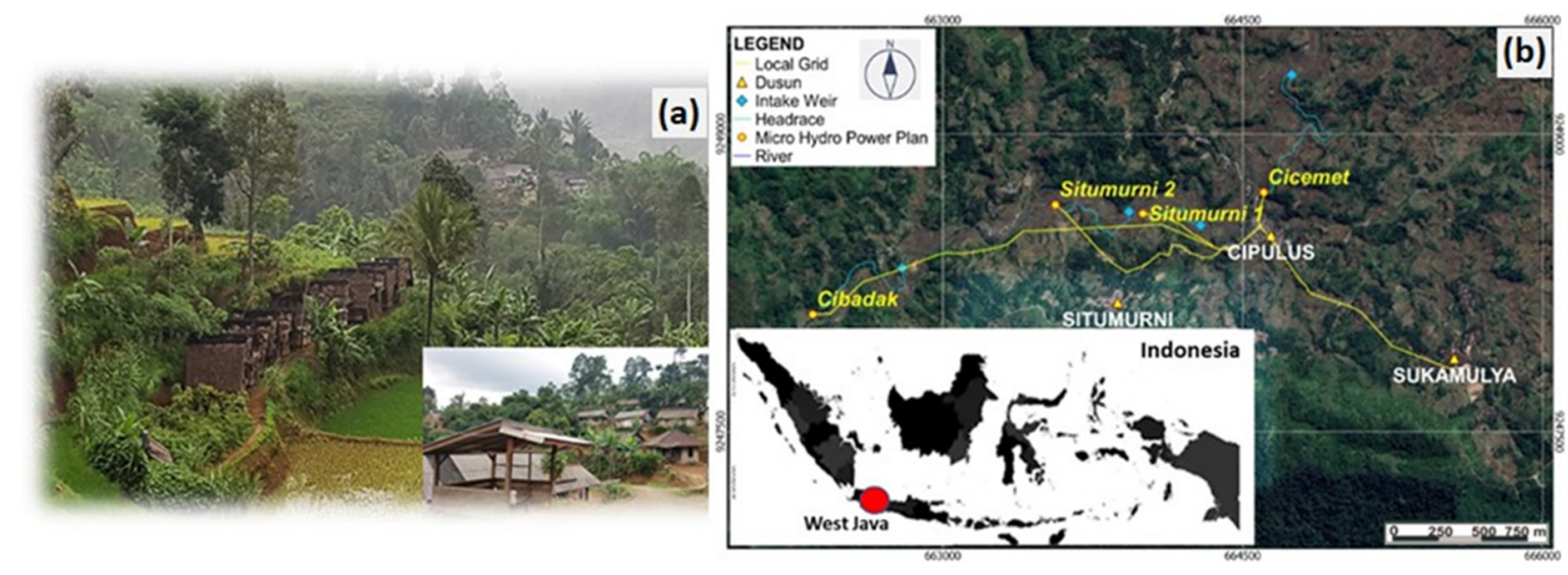

Figure 1. (a) Landscape of the Ciptagelar village. (b) Study location and layout of four MHP plants.

Kasepuhan Ciptagelar is a traditional community with a unique social structure; it has local wisdom in managing natural resources and lives under its leader's orientation. Every person in Kasepuhan Ciptagelar works as a subsistence farmer. The people of Ciptagelar believe that the rice entity is imprinted in the realm of values and thought and is reflected in ritual and daily life. They prioritize the balance between humans and nature, and this concept of balance is implemented in agriculture and forest management whereby humans can take advantage of nature for their lives but must not cause damage. The highest leader of the Kasepuhan community is called Abah, and his role and influence are significant in the community. The leader plays a role in determining the entire cycle of customary activities, including agriculture and forest management and resolving social problems that occur in the community by providing warnings and reprimands for those who are culpable. The traditional leader is believed to have a relationship with their ancestors, and every decision is part of their blessing.

There are four MHPPs in Kasepuhan Ciptagelar: Cicemet, Situmurni 1, Cibadak, and Situmurni 2 (Figure 1). MHPPs have been developed under the Indonesian local government's support along with non-governmental organizations (NGOs), the Korea International Cooperation Agency (KOICA), and the Japan International Cooperation Agency (JICA). All MHPPs are located on the Cisono River in the Cibareno watershed, which has an area of $\pm 229,834 \mathrm{~m}^{2}$. Currently, the Cicemet MHPP, which started operations in 1998, is damaged. In addition, the Situmurni 1 MHPP, which began operation in 2001, cannot supply electricity to the communities. They have been broken since March 2016 due to massive floods, landslides, and thunderstorms caused by extreme weather conditions. The other two MHPPs, Cibadak and Situmurni 2, remain in operation and are generally in good condition; they have been used for the sustainability assessment.

\subsection{Investigation and Analysis}

\subsubsection{Sustainable Development Indicator Analysis}

This study proposed a sustainable indicator framework by Ilskog [21], which covers multiple sustainability dimensions, including social, economic, environmental, technical, and institutional dimensions (IDs). In total, 29 indicators were used to assess the MHP plants, which were selected based on a preliminary survey and their field applicability. The investigations were conducted through surveys, interviews, and document checking. 
Household electricity consumption was calculated by checking the ownership of electronic devices in the customer's book and verified during the interview process; data were collected between November 2019 and January 2020.

The value of each indicator was obtained from the survey and determined using the indicator equation. The level of sustainable development indicators (SDI) is calculated by comparing its value with its target level. The target level for each indicator was derived from literature that offers the experience of the best hydropower projects. In choosing the target levels, the standard value was purposely set high to show the sustainability dimensions' positive results [22]. The equations to determine the indicator values and their target levels can be seen in the Appendix A (Table A1). The SDI score of each indicator was $100 \%$ if the indicator reached the target. If the indicator's value was below the target with the minimum requirement, the SDI score was calculated using Equation (1). Conversely, if it exceeded the target with the maximum target, the SDI score was calculated using Equation (2) [14]. The total SDI value for each MHPP resulted from the arithmetic averages of all SDI values, which also indicated that each indicator had the same weight. Equations (1) and (2) are calculated as follows:

$$
\begin{gathered}
\text { SDI }(\%)=\mathrm{Vi} / \mathrm{Vt} \times 100 \% \\
\mathrm{SDI}(\%)=100 \%-(\mathrm{Vi}-\mathrm{Vt}) / \mathrm{Vt} \times 100 \%
\end{gathered}
$$

where:

SDI: score of the sustainable development indicator;

Vi: value of the indicator;

$\mathrm{Vt}$ : value of the target level.

\subsubsection{Social Surveys}

In-depth interviews with respondents were conducted face-to-face, in a semi-structured way to obtain broad and comprehensive information. The respondents were asked questions related to their education, livelihood, income, and perception of MHPP. The documents checked were a financial book that records consumer contributions. The population consisted of 508 households with an electrical connection to an MHPP within three hamlets: Cipulus, Situmurni, and Sukamulya. The number of samples was determined using the Slovin equation, and the critical value was set to $10 \%$. The sample size was 84 , representing a family head in each household. Respondents were selected using the random walk sampling method because the area of each hamlet is not too large. The calculation of electrical device ownership was based on the customer's book and confirmed during the interview.

\subsubsection{Land Cover Analysis}

Cibareno's watershed land cover was analyzed using satellite imagery and a geographical information system (GIS). GIS software can analyze and display geographical referenced (spatial) information to aid decision-making processes [23]. The image source was the Landsat 8 onboard operational land imager (OLI) in 2019. Spatial analysis of the vegetation index was used to classify land cover into six parts: river, paddy and wet areas, settlements, barren land, medium-density forests, and high-density forests. The vegetation area was the sum of the areas classified as medium-density and high-density forests. The regulation of the Minister of Forestry of the Republic of Indonesia was used as a reference to determine watershed conditions.

\section{Results}

\subsection{General Situations for Kasepuhan Ciptagelar}

The social investigation obtained information related to education level, livelihood, and monthly income. The academic history of most people in Kasepuhan Ciptagelar is of elementary school graduation. The primary school in Kasepuhan Ciptagelar was established in 2003. Most people work as farmers and some people earn additional income 
by working as temporary laborers and selling local handicrafts. They face uncertain monthly payments. As many as 31\% of people earn an income between USD 60 and USD 110 per month, and $69 \%$ earn incomes below USD 60 per month. Most have one or two children. Farmers in Kasepuhan usually work from 8.00 a.m. to 3.00 p.m.

The life of the Kasepuhan community is oriented toward traditional leaders, to whom they are very obedient. Traditional leaders (Abah) are seen as symbols and must be respected by the community. There is a belief in society that Abah's orders must be fulfilled, and every decision he makes is part of a blessing from the ancestors. They believe that his orders will do good, and if they are not followed, they will incur losses. A small organization led by the Kasepuhan leader operates the two MHPPs, indicating that the MHPP presence is crucial for the lives of the people of Kasepuhan. The organization consists of six staff members, two of which have technical capabilities from the training held by the local government and contractor.

The semi-structured interview revealed the reasons for the community's strong commitment to the MHP. According to a quote from one of the traditional elders, "The existence of the MHP in Kasepuhan was initiated by traditional leader and built by the extraordinary work of the Kasepuhan community in cooperation; therefore, it must be maintained and utilized for the benefit of the Kasepuhan community". The majority of respondents also convey this perception.

The MHPP tariff in Kasepuhan Ciptagelar uses a fixed scheme of Rupiah (Rp) 400 watt $^{-1}$. This tariff was the same as when the MHPPs were established in 1997. There was a compromised wattage calculation chosen by the previous leader that the watts for each electronic device owned by the customer were only half of the specification values. This means that each household pays based on the type of electronics they own.

Field investigations included checking all MHPP conditions and calculating household electricity consumption. Currently, only two MHPPs remain in operation, Cibadak and Situmurni 2. The characteristics of all the MHPPs are presented in Table 1. In the surveys, people were asked about their electronic device use habits. Electricity for each house was limited to 2 amperes by a miniature circuit breaker (MCB). Based on the calculation of equipment ownership and use habits, the average value of electricity consumption was

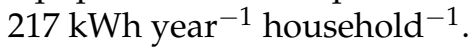

Table 1. Characteristics of micro-hydro technology.

\begin{tabular}{cccccc}
\hline MHP Plants & Turbine & Head $(\mathbf{m})$ & Flow (L/s) & Output (kW) & Generator \\
\hline Cicemet * & Cross flow & 17 & 348 & 60 & - \\
\hline Cibadak & Cross flow & 15 & 300 & 58 & Synchronous \\
\hline Situmurni 2 & Cross flow & 13.5 & 349 & 48 & Synchronous \\
\hline Situmurni 1 * & $\begin{array}{c}\text { Turbo } \\
\text { Propeller }\end{array}$ & 11.5 & 397 & 40 & Synchronous \\
\hline * out of operation. & & & &
\end{tabular}

\subsection{Land Cover}

The Cibareno watershed has an area of $\pm 22,983$ ha and is classified as shown in Figure 2. The land cover of the Cibareno watershed is divided into five areas: river bodies covering \pm 282 ha (1.23\%), agricultural land and rice fields covering \pm 2272 ha $(9.89 \%)$, residential open land covering \pm 255 ha $(1.11 \%)$, dry soil with sparse vegetation covering \pm 4970 ha $(21.63 \%)$, and medium-high density vegetation covering $\pm 15,203$ ha $(66.15 \%)$. 


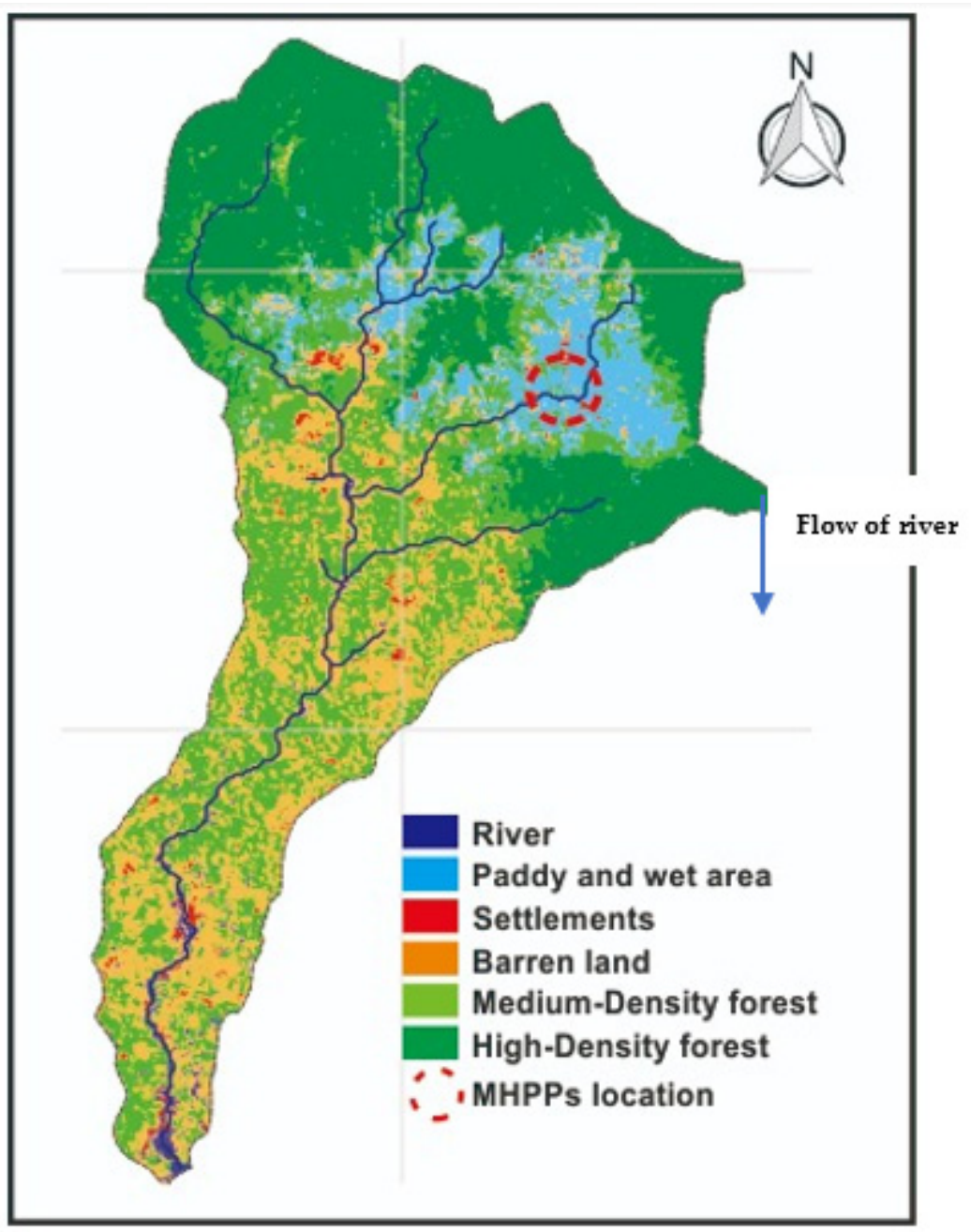

Figure 2. Land cover of the Cibareno watershed.

\subsection{Sustainable Development Indicators Score}

The assessment covered the five sustainable development dimensions. Table 2 provides the value of each indicator based on the data collected during the field investigation.

In general, most technical indicators approached their target level, except for the capacity factor indicator, which only reached half of the specified target. The grid system at the Cibadak plant was better than that at the Situmurni 2 plant because it followed the national network's standard technology. The opposite result was found for the economic dimension indicators, where the majority of indicators produced values below the specified target level. The indicator exceeding the target was the profitability indicator, which showed the percentage of income after deducting operational costs (salary). Currently, there is a Ciptagelar coffee production unit that utilizes electricity from the Cibadak plant.

Social indicators (SIs), environmental indicators (EIs), and institutional indicators (IIs) showed different results. Most SIs were close to reaching the target level $(>70 \%)$. The unavailability of micro-credit facilities and streetlights comprised the two social dimension indicators, which provided low values. The EIs showed the best sustainability because almost all indicators reached the target levels. Only the indicator of electricity utilization for cooking (EI4) was low. The IIs showed only two indicators, staff turnover (II2) and number of years in business (II3), that reached the target levels; the indicator of satisfaction level (II5) was slightly below its target level, and the indicators related to non-technical losses (II4) and financial audits (II6) received low scores.

The total SDI scores of the Cibadak MHPP and Situmurni 2 MHPP were $67 \%$ and $61 \%$, respectively, and the average score was $64 \%$ (Figure 3). The environmental dimension (ED) 
showed the highest score among all dimensions, followed by the institutional (ID), social (SD), technical (TD), and economic dimensions (BD).

Table 2. Result of indicator value.

\begin{tabular}{|c|c|c|c|c|}
\hline & \multirow{2}{*}{ Sustainability Indicator } & \multirow{2}{*}{ Target Level } & \multicolumn{2}{|c|}{ Indicator Value } \\
\hline & & & Cibadak & Situmurni 2 \\
\hline \multicolumn{5}{|c|}{ Technical Indicators (TI): } \\
\hline- & Capacity factor (TI1) & Min 95\% & $49.5 \%$ & $55 \%$ \\
\hline- & Compatibility with future grid services (TI2) & Yes & Yes & No \\
\hline- & Daily operation services (TI3) & $24 \mathrm{~h}$ & $24 \mathrm{~h}$ & $24 \mathrm{~h}$ \\
\hline- & Availability of services (TI4) & $100 \%$ & $91 \%$ & $94 \%$ \\
\hline \multicolumn{5}{|c|}{ Economic Indicators (BI): } \\
\hline- & Profitability (BI1) & Min 35\% & $63 \%$ & $41 \%$ \\
\hline- & Share of profit set aside for re-investment (BI2) & $100 \%$ & $9 \%$ & $8 \%$ \\
\hline- & Tariff lag (BI3) & Min $21 \%$ & $0 \%$ & $0 \%$ \\
\hline- & Share of electricity consumed by businesses (BI4) & Min 5\% & $0.95 \%$ & $0 \%$ \\
\hline- & Share of electricity households for income (BI5) & $\operatorname{Min} 5 \%$ & $2.6 \%$ & $0 \%$ \\
\hline- & Business development (BI6) & Min 1 unit & 1 & 0 \\
\hline \multicolumn{5}{|c|}{ Social Indicators (SI): } \\
\hline- & Share of health centers and school with electricity (SI1) & Min $90 \%$ & $100 \%$ & $100 \%$ \\
\hline- & Number of streets lights in the area (SI2) & Min 1/40 & 0 & 0 \\
\hline- & Micro-credit possibilities available for connection (SI3) & Min 1 unit & 0 & 0 \\
\hline- & Share of population with primary school education (SI4) & Min $80 \%$ & $92 \%$ & $95 \%$ \\
\hline- & Share of population with access to electricity (SI5) & Min $90 \%$ & $100 \%$ & $100 \%$ \\
\hline- & Subsidies offered for electricity services (SI6) & $\operatorname{Max} 1 \%$ & $0.97 \%$ & $2.47 \%$ \\
\hline- & Share of economically active children (SI7) & $\operatorname{Max} 5 \%$ & $2 \%$ & $1 \%$ \\
\hline \multicolumn{5}{|c|}{ Environmental Indicators (EI): } \\
\hline- & Share of renewable energy in production (EI1) & $100 \%$ & $100 \%$ & $100 \%$ \\
\hline- & Emissions of carbon dioxide from production (EI2) & 0 Ton $\mathrm{CO}_{2} / \mathrm{yr}$ & 0 Ton $\mathrm{CO}_{2} /$ yr. & 0 Ton $\mathrm{CO}_{2} / \mathrm{yr}$. \\
\hline- & $\begin{array}{l}\text { Share of electrified households where electricity has replaced } \\
\text { other energy source for lighting (EI3) }\end{array}$ & $100 \%$ & $100 \%$ & $100 \%$ \\
\hline- & $\begin{array}{l}\text { Share of electrified households where electricity has replaced } \\
\text { other energy source for cooking (EI4) }\end{array}$ & Min 50\% & $0 \%$ & $0 \%$ \\
\hline- & Any serious local environment impact identified (EI5) & No & No & No \\
\hline- & Extreme weather condition (EI6) & Never & Never & Never \\
\hline \multicolumn{5}{|c|}{ Institutional Indicators (II): } \\
\hline- & Share of staff with appropriate education (II1) & Min 50\% & $33 \%$ & $33 \%$ \\
\hline- & Staff turnover in organization (II2) & $0 \%$ & $0 \%$ & $0 \%$ \\
\hline- & Number of years in business (II3) & Min 5 yr. & 7 yr. & $6 \mathrm{yr}$. \\
\hline- & Share of non-technical losses (II4) & $0 \%$ & $20.21 \%$ & $20.77 \%$ \\
\hline- & Level of satisfaction with energy services (II5) & $100 \%$ & $98 \%$ & $96 \%$ \\
\hline- & Auditing of financial reports on yearly basis (II6) & Once/yr. & 0 & 0 \\
\hline
\end{tabular}



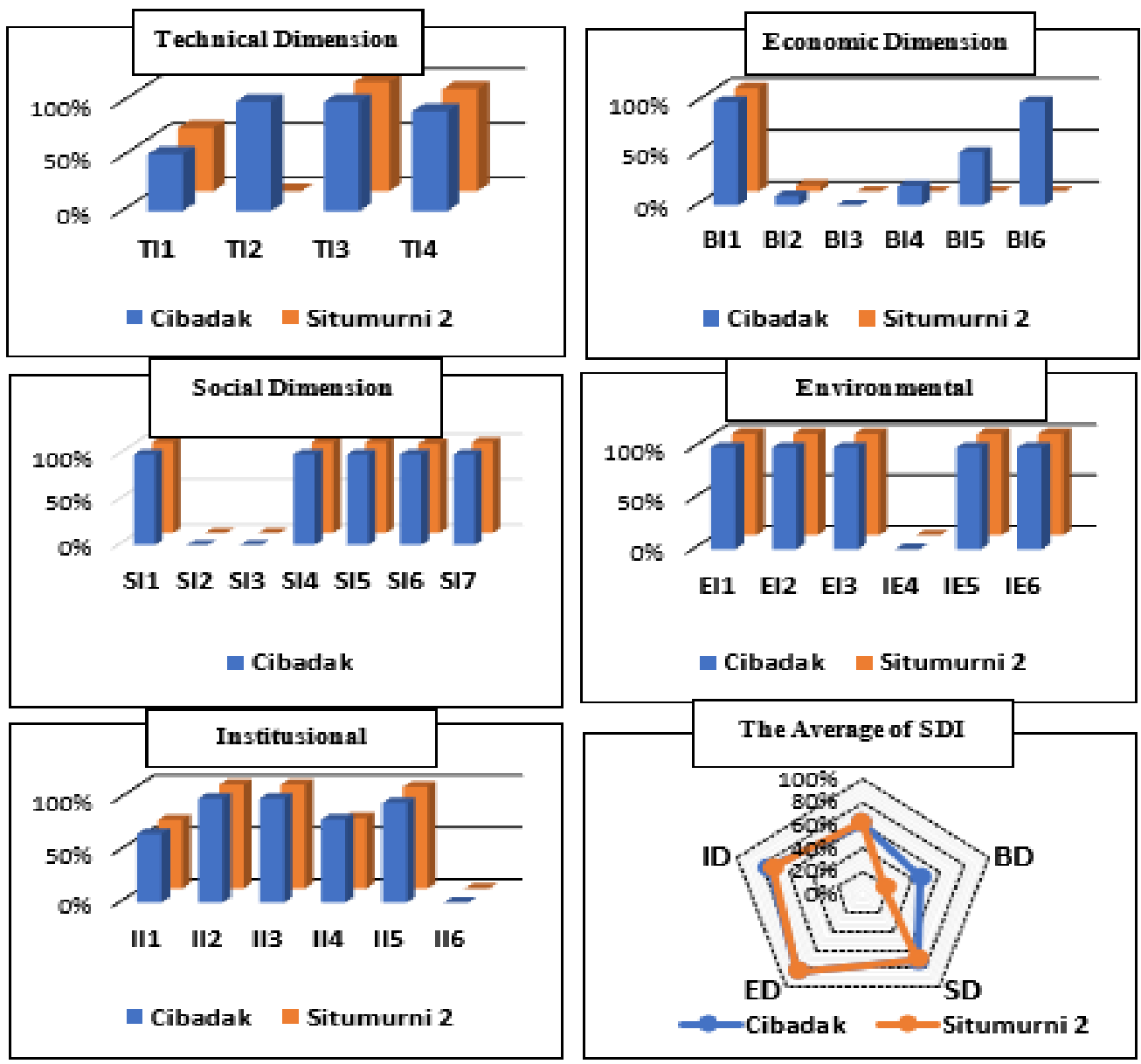

Figure 3. Sustainable development indicator (SDI) scores. See Table 2 for the abbreviations in the figure.

\section{Discussion}

Environmental sustainability can be seen as a global and local factor. Global environmental sustainability's primary considerations relate to the emission of greenhouse gases, such as $\mathrm{CO}_{2}$, while the local factors relate to natural resource disruption [21]. The indicators of the share of renewable energy and carbon emissions represent global impact factors, which approached the target level. Based on the field survey, MHPPs were the only electrification resources for people in the Kasepuhan Ciptagelar, which emit no $\mathrm{CO}_{2}$. The qualitative study found that the strong commitment of people in the Kasepuhan area was always to utilize MHPPs. This was largely attributable to the Kasepuhan leader's decisions. The village people explained that the presence of the MHPP was an extraordinary result accomplished by their leader, together with people in Kasepuhan. Moreover, the Kasepuhan leader regularly asked people to commit to preserving all MHPPs so that electricity can be utilized from generation to generation. The traditional leader in Kasepuhan Ciptagelar is a figure who is able to enforce community involvement in participatory activities, and his order must be followed and executed by the communities [24].

Among the EIs, only EI4 did not reach the target level. Kasepuhan Ciptagelar has customary rules in how rice is cooked; it must be cooked using firewood. Only some people, about $31 \%$ of households, were gas owners allowing them to prepare other meals, such as meat, vegetables, or side dishes. People received wood from their gardens or bought it from a supplier. A survey by the World Bank [25] found that approximately $40 \%$, or 25.5 million households, use firewood for cooking, especially in remote villages. Firewood is preferable because it is easy to find and free. However, electricity for cooking could reduce the 13-35 ton- $\mathrm{CO}_{2}$ year $^{-1}$ emissions [26]. One challenge is how residents should prevent their forest from being overexploited considering the high demand for wood for 
cooking and other purposes. In Ciptagelar, based on customary rules, forest utilization is divided into three zones: a close zone (Leuweung Tutupan), an open zone (Leuweung Bukaan), and a security zone (Leuweung Titipan). Even though there is no clear border between the zones, the people of Kasepuhan know the area's characteristics precisely. People can only exploit open-zone forests to support their lives. The commitment of the community to protect forests based on customary rules impacts forest preservation. This supports the sustainability of the ED, especially the indicators related to local factors (EI5 and EI6). Based on the satellite image analysis, the land cover of the Cibareno watershed by vegetation with high-medium density was more than $60 \%$. Areas with high-medium vegetation density between $60 \%$ and $80 \%$ were characterized as having low restoration [27]. However, traditional leaders and forest caretakers (Pasmswakarsa) still have to regularly supervise the forest to avoid illegal logging that causes environmental damage. Waddell and Bryce [28] reported that forest preservation is a crucial factor in sustainable environmental determination. MHP generation as an energy source is a tool to achieve the final goals, including high living standards and a clean environment [29].

The BD was the weakest point in the sustainable development of rural electrification. The indicators (BI) showed that the community's economic activity was low; ultimately, it impacted the ability of the community to increase electricity fees over time. Rice farming is the main economic activity in the community. However, the customary rules prohibit people from selling paddies. Moreover, rice can only be planted once per year. They believe that whoever buys or sells rice will receive bad luck from their ancestors. This situation might impact the income of Kasepuhan. At present, electricity from the Cibadak MHPP has been utilized for coffee processing since 2014. To overcome this financial situation, the Kasepuhan community should increase its economic activity.

Based on the field investigation, the first important factor in generating productive activities is capacity building, creating markets, and providing credit facilities. Capacity building will improve the ability of people to think more innovatively, where the markets offer people the opportunity to sell their products. People need credit facilities to help them acquire capital to develop businesses. According to Sukma [30], approximately $69 \%$ of the Kasepuhan community had experience in borrowing money, such as from banks. Potentially, some traditional handcrafts from wood and iron materials could be developed commercially, such as rattan bags (called Kaneron), bracelets, rings made from fern trees (called Simpay), machetes (Bedog), and a tool for paddy cutting (called Etem). External assistance is needed to promote economic activities for the Kasepuhan communities. The local government could be a triggering party and facilitator for other stakeholders in realizing open market and credit activities. Innovation and capacity building are the basic requirements for creating productive activities [23], which could increase the communities' income; thus, the sustainable economy of MHPs can be achieved [31]. People living in villages in developing countries will benefit from MHPPs for economic growth if the energy is optimally used for productive activities [1,32].

Traditional leaders have a strong influence on Kasepuhan's lives. The Kasepuhan community express their leader as a symbol, and everyone must follow his orders. They believe that it will affect their welfare if they participate in the leader's orders. This perception could be the best way to support sustainable MHP development in Kasepuhan Ciptagelar. For example, the decision of traditional leaders to provide electricity subsidies to older people and social infrastructure helps SIs reach the target levels. For IDs, the decision of traditional leaders to keep staff members unchanged in the MHP organization supports institutional sustainability, especially turnover staff indicators. One determining factor for an institution's sustainability is staff turnover [33,34]. Meanwhile, the challenge in the ID concerns the non-technical indicator showing the obedience of customers in paying electricity bills. The role of the leader is crucial in monitoring financial management, including an audit of the MHP management organization in collaboration with external parties. It is necessary to make and implement acceptable rules, especially those related to the payment of contributions. There is no negotiation in terms of payment for electricity 
bills [35]. The concept of sustainable institutions requires the implementation of strict rules. Simple and acceptable rules with accountable supervision are the key successes of institutional management in achieving sustainable development [36].

\section{Conclusions}

The SDI method could identify and understand the strongest and most vulnerable dimensions related to the sustainability of MHP plants in Kasepuhan Ciptagelar. This study revealed that the EDs were the strongest in terms of the sustainability of MHPPs, whereas the economic dimension was the weakest. The strong commitment of the community to preserve MHPPs as the primary source of electricity supports environmental sustainability. In Ciptagelar, there has been a community perception that MHP is a part of their culture, which has to be preserved from generation to generation. However, strict customary rules and subsequent low monetary incomes have made it difficult to sustain MHPPs. Therefore, communities need to participate more willingly in productive activities based on MHP generation. Capacity building, creating markets, and providing credit facilities are the main factors that trigger productive activities, which could be achieved through cooperation with external parties such as the local government, NGOs, and other stakeholders.

Author Contributions: Conceptualization and methodology, M.A.I. and P.S.; investigation, M.A.I., J.I., T.S., N.O., I.E. and A.T.; formal analysis, writing—original draft preparation, M.A.I.; writingreview and editing, J.I., T.S., N.O., I.E. and A.T.; supervision, P.S. and B.S.M.; funding acquisition, M.A.I., J.I. and T.S. All authors have read and agreed to the published version of the manuscript.

Funding: This research was supported in part by the Ministry of Energy and Mineral Resources of Indonesia, a grant for Future Earth Study from the JST-RISTEX (JPMJRX16F1), the EIG CONCERTJapan: Smart Water Management for Sustainable Society from the JST (JPMJSC19C3), a Grant-in-Aid for Scientific Research from the JSPS (\#JP15K16115; \#JP18K11623; \#JP21K18113), and a research grant from the Mitsui \& Co. Environment Fund (\#R19-0026).

Institutional Review Board Statement: The study was conducted with permittion number 070/3106/ SKP/XI/2019, from The National Unity, Politics, and Community Protection Agency, West Java Province.

Informed Consent Statement: Informed consent was obtained from all subjects involved in the study.

Data Availability Statement: The data presented in this study are available from the corresponding author on reasonable request. The data are not publicly available due to the privacy which contains personal information.

Acknowledgments: The authors would like to thank the Ciptagelar community for their help and hospitality during the field investigations.

Conflicts of Interest: The authors declare no conflict of interest. The funders had no role in the study design; in the collection, analyses, or interpretation of data; in the writing of the manuscript; or in the decision to publish the results.

\section{Appendix A}

Table A1. Equations to determine the indicator values and their target level.

\begin{tabular}{|c|c|c|c|c|}
\hline No. & Indicator * & How to Measure * & Unit & Target Level Determination ** \\
\hline \multicolumn{5}{|c|}{ Technical } \\
\hline 1 & Capacity Factor & $\begin{array}{l}\text { The gross energy }(\mathrm{kWh}) \text { divided by } \\
\text { the total installed capacity }(\mathrm{kW}) \text { when } \\
\text { the plant operated for } 8760 \mathrm{~h} / \mathrm{yr}\end{array}$ & $\%$ & $\begin{array}{c}\text { Capacity factors of hydropower } \\
\text { projects worldwide yield between } \\
23 \% \text { and } 95 \%\end{array}$ \\
\hline 2 & $\begin{array}{l}\text { Compatibility with } \\
\text { national grid }\end{array}$ & Field Survey & Yes/No & $\begin{array}{l}\text { To increase its sustainability, } \\
\text { MHPPs should be readily } \\
\text { interconnected in the future, and } \\
\text { follow the national grid } \\
\text { standard installation. }\end{array}$ \\
\hline
\end{tabular}


Table A1. Cont.

\begin{tabular}{|c|c|c|c|c|}
\hline No. & Indicator * & How to Measure * & Unit & Target Level Determination ** \\
\hline 3 & Daily operation Services & Hours of daily's operation hours & Hour & $\begin{array}{l}\text { Electricity is essential, and people } \\
\text { need it all the time. The target is } \\
24 \mathrm{~h} \text { a day. }\end{array}$ \\
\hline 4 & Service availability & $\begin{array}{l}\text { Number of hours electricity's in the } \\
\text { planning minus hours of outages; } \\
\text { divided by the number of hours } \\
\text { electricity's in planning }\end{array}$ & $\%$ & The best service availability is $100 \%$ \\
\hline \multicolumn{5}{|c|}{ Economic } \\
\hline 5 & Profitability & $\begin{array}{l}\text { Total profit (revenue }- \text { O\&M cost }) \\
(\mathrm{Rp} / \mathrm{yr}), \text { divided by total revenue } \\
(\mathrm{Rp} / \mathrm{yr}) \times 100 \%\end{array}$ & $\%$ & $\begin{array}{l}\text { The average profitability of } \\
\text { micro-hydro in Indonesia is } \\
\text { around } 35 \%\end{array}$ \\
\hline 6 & $\begin{array}{l}\text { Share of profit set aside for } \\
\text { re-investment }\end{array}$ & $\begin{array}{c}\text { The total profit (revenue }- \text { O\&M cost) } \\
(\mathrm{Rp} / \mathrm{yr}) \text {, divided by the total cost of } \\
\text { equipment depreciation } \\
(\mathrm{Rp} / \mathrm{yr}) \times 100 \%\end{array}$ & $\%$ & $\begin{array}{l}\text { The visibility of a good project has } \\
\text { an investment rate of at least } 100 \% \text {. }\end{array}$ \\
\hline 7 & Tariff lag & $\begin{array}{l}\text { The ratio between the change of } \\
\text { electricity tariff }(\%) \text { and change in } \\
\text { inflation }(\%) \times 100 \%\end{array}$ & $\%$ & $\begin{array}{c}\text { The economic feasibility analysis of } \\
\text { the MHP projects in Wonosobo, } \\
\text { Indonesia, determined that the tariff } \\
\text { increases annually by } 3 \%\end{array}$ \\
\hline 8 & $\begin{array}{c}\text { Share of electricity consumed } \\
\text { by businesses }\end{array}$ & $\begin{array}{l}\text { The ratio between electrification for } \\
\text { businesses }(\mathrm{kWh} / \mathrm{yr}) \text { and the net of } \\
\text { electrical production } \\
(\mathrm{kWh} / \mathrm{yr}) \times 100 \%\end{array}$ & $\%$ & $\begin{array}{l}\text { As much as } 5 \% \text { of the minimal of } \\
\text { electricity consumed for the } \\
\text { business to generate income and } \\
\text { significant change of economic }\end{array}$ \\
\hline 9 & $\begin{array}{l}\text { Share of electricity households } \\
\text { for income }\end{array}$ & $\begin{array}{l}\text { The ratio between electrifying use for } \\
\text { household businesses }(\mathrm{HH}) \text { and the } \\
\text { total number of households } \\
\text { electrification }(\mathrm{HH}) \times 100 \%\end{array}$ & $\%$ & $\begin{array}{l}\text { The minimum is } 10 \% \text { for the } \\
\text { target level }\end{array}$ \\
\hline 10 & Business development & $\begin{array}{l}\text { Number of businesses development } \\
\text { on yearly basis }\end{array}$ & unit & $\begin{array}{l}\text { One business has been developed } \\
\text { as the minimum target }\end{array}$ \\
\hline \multicolumn{5}{|c|}{ Social } \\
\hline 11 & $\begin{array}{l}\text { Share of health centers and } \\
\text { school with electricity }\end{array}$ & $\begin{array}{l}\text { The ratio between the number of } \\
\text { electrified public center (unit) and the } \\
\text { total number of public center (Unit) } \times \\
100 \%\end{array}$ & $\%$ & $\begin{array}{l}\text { The electricity share for health } \\
\text { facilities and schools is between } \\
70-100 \% \text {. Set the target at } 90 \%\end{array}$ \\
\hline 12 & $\begin{array}{c}\text { Number of streetlights in the } \\
\text { area }\end{array}$ & $\begin{array}{l}\text { Streetlights are available every forty } \\
\text { meters }\end{array}$ & unit & $\begin{array}{c}\text { The target number of streetlights is } \\
\text { one for every } 40 \mathrm{~m}\end{array}$ \\
\hline 13 & $\begin{array}{l}\text { Micro-credit possibilities } \\
\text { available for connection }\end{array}$ & $\begin{array}{l}\text { Number of microcredits available in } \\
\text { the area }\end{array}$ & unit & $\begin{array}{l}\text { At least one microcredit service is } \\
\text { available }\end{array}$ \\
\hline 14 & $\begin{array}{l}\text { Share of population with } \\
\text { primary school education }\end{array}$ & $\begin{array}{l}\text { The ratio between the number of } \\
\text { adult inhabitants with elementary } \\
\text { school education (person) and the } \\
\text { total number of adult } \\
\text { inhabitants } \times 100 \%\end{array}$ & $\%$ & $\begin{array}{c}\text { Electricity is provided for the entire } \\
\text { household. }\end{array}$ \\
\hline 15 & $\begin{array}{l}\text { Share of population with } \\
\text { access to electricity }\end{array}$ & $\begin{array}{l}\text { The ratio between number of } \\
\text { electrified households (person) } \\
\text { multiplied by average inhabitants per } \\
\text { household and the total number } \\
\text { of inhabitants }\end{array}$ & $\%$ & $\begin{array}{l}\text { Electricity is provided for the } \\
\text { entire households }\end{array}$ \\
\hline 16 & $\begin{array}{l}\text { Subsidies offered for } \\
\text { electricity services }\end{array}$ & $\begin{array}{c}\text { Number of electricity bills that are } \\
\text { subsidized (Rp/yr) divided by the } \\
\text { total number of electricity bills } \\
(\mathrm{Rp} / \mathrm{yr})\end{array}$ & $\%$ & Set as maximum $1 \%$ \\
\hline 17 & $\begin{array}{l}\text { Share of economically } \\
\text { active children }\end{array}$ & $\begin{array}{l}\text { Number of economically active } \\
\text { children (person) divided by the } \\
\text { number of children (person) }\end{array}$ & $\%$ & $\begin{array}{l}\text { Set the maximum share of } \\
\text { economically active children as } 5 \%\end{array}$ \\
\hline \multicolumn{5}{|c|}{ Environment } \\
\hline 18 & $\begin{array}{l}\text { Share of renewable energy } \\
\text { in production }\end{array}$ & $\begin{array}{l}\text { Gross electricity production from } \\
\text { micro-hydro (kWh/yr) divided by } \\
\text { total electricity production }(\mathrm{kWh} / \mathrm{yr})\end{array}$ & $\%$ & Set the highest target as $100 \%$ \\
\hline
\end{tabular}


Table A1. Cont.

\begin{tabular}{|c|c|c|c|c|}
\hline No. & Indicator * & How to Measure * & Unit & Target Level Determination ** \\
\hline 19 & $\begin{array}{l}\text { Emissions of carbon dioxide } \\
\text { from production }\end{array}$ & $\begin{array}{l}\text { Gross electricity of } \mathrm{MHP}(\mathrm{kWh} / \mathrm{yr}) \text {, } \\
\text { multiplied by emission factor (ton } \\
\left.\qquad \mathrm{CO}_{2} / \mathrm{kWh}\right)\end{array}$ & $\begin{array}{l}\text { Ton } \\
\mathrm{CO}_{2} / \mathrm{kwh}\end{array}$ & $\begin{array}{l}\text { For Sustainable development, the } \\
\text { target is set as } 0 \text { ton } \mathrm{CO}_{2}\end{array}$ \\
\hline 20 & $\begin{array}{c}\text { Share of Electrified households } \\
\text { where electricity has replaced } \\
\text { other energy source } \\
\text { for lighting }\end{array}$ & $\begin{array}{l}\text { The ratio between the number of } \\
\text { Households that use electricity for } \\
\text { lighting }(\mathrm{HH}) \text { and the total } \\
\text { households }(\mathrm{HH})\end{array}$ & $\%$ & $\begin{array}{c}\text { The target minimum is set as } 100 \% \\
\text { for electricity as a source } \\
\text { for lighting }\end{array}$ \\
\hline 21 & $\begin{array}{c}\text { Share of Electrified households } \\
\text { where electricity has replaced } \\
\text { other energy source } \\
\text { for cooking }\end{array}$ & $\begin{array}{l}\text { The ratio between the number of } \\
\text { Households that use electricity for } \\
\text { cooking }(\mathrm{HH}) \text { and the total } \\
\text { households }(\mathrm{HH})\end{array}$ & $\%$ & $\begin{array}{l}\text { The target minimum is set as } 50 \% \\
\text { for electricity as a source } \\
\text { for cooking }\end{array}$ \\
\hline 22 & $\begin{array}{l}\text { Any serious environment } \\
\text { impact identified }\end{array}$ & Survey identification & Yes/No & $\begin{array}{l}\text { The PLTMH causes no } \\
\text { environmental impacts }\end{array}$ \\
\hline 23 & Extreme weather condition & $\begin{array}{l}\text { Number of times the project disturbed } \\
\text { by extreme weather }\end{array}$ & Times & $\begin{array}{l}\text { The target set that there were no } \\
\text { extreme conditions that would } \\
\text { disrupt the operation of the MHPPs }\end{array}$ \\
\hline \multicolumn{5}{|c|}{ Institutional } \\
\hline 24 & $\begin{array}{l}\text { Share of staff with } \\
\text { appropriate education }\end{array}$ & $\begin{array}{l}\text { The ratio between the number of staff } \\
\text { with technical background and the } \\
\text { total staff }\end{array}$ & $\%$ & $\begin{array}{l}\text { At least two staff members have } \\
\text { technical skills. This study set } \\
\text { minimum staff as many } 50 \%\end{array}$ \\
\hline 25 & Staff turnover in organization & $\begin{array}{l}\text { The ratio between the number of staff } \\
\text { that leave and total staff }\end{array}$ & $\%$ & $\begin{array}{c}\text { Staff turnover will have a negative } \\
\text { impact. A minimum target is set to } \\
\text { be no turnover }\end{array}$ \\
\hline 26 & Number of years in business & Total number operation of MHP & Year & $\begin{array}{l}\text { The operation time of MHP was } \\
\text { approximately } 66 \text { months. }\end{array}$ \\
\hline 27 & Share of non-technical losses & $\begin{array}{c}\text { Total unpaid bills }(\mathrm{Rp} / \mathrm{yr}), \text { divided by } \\
\text { total bills }(\mathrm{Rp} / \mathrm{yr})\end{array}$ & $\%$ & $\begin{array}{l}\text { The smaller, the better; the } \\
\text { minimum value was set to be } 0 \%\end{array}$ \\
\hline 28 & $\begin{array}{l}\text { Level of satisfaction with } \\
\text { energy services }\end{array}$ & $\begin{array}{l}\text { The ratio between the number of } \\
\text { electrified households that are } \\
\text { satisfied and the total number } \\
\text { of households }\end{array}$ & $\%$ & $\begin{array}{c}\text { The more people satisfied, the } \\
\text { better. This study set the maximum } \\
\text { value as } 100 \%\end{array}$ \\
\hline 29 & $\begin{array}{l}\text { Auditing of financial reports } \\
\text { on yearly basis }\end{array}$ & $\begin{array}{l}\text { Number of times audited report on a } \\
\text { yearly basis }\end{array}$ & times & $\begin{array}{l}\text { Set the minimum target as one time } \\
\text { audit in this study }\end{array}$ \\
\hline
\end{tabular}

*Adaptation from Ilskog (2008); ** Adaptation from Purwanto dan Afifah (2018).

\section{References}

1. Paish, O. Small hydro power: Technology and current status. Renew. Energy Sustain. Energy Rev. 2002, 6, 537-556. [CrossRef]

2. Arnaiz, M.; Cochrane, T.A.; Calizaya, A.; Shrestha, C. A framework for evaluating the current level of success of micro-hydropower schemes in remote communities of developing countries. Energy Sustain. Dev. 2018, 44, 55-63. [CrossRef]

3. Laghari, J.A.; Mokhlis, H.; Bakar, A.H.A.; Mohammad, H. A comprehensif overview of new designs in the hydraulic, electrical equipments and controllers of mini hydro power plants making it cost effective technology. Renew. Sustain. Energy Rev. 2013, 20, 279-293. [CrossRef]

4. Date, A.; Akbarzadeh, A. Design and cost analysis of low head simple reaction hydro turbine for remote area power supply. Renew. Energy 2009, 34, 409-415. [CrossRef]

5. Mujiyanto, S.; Tiess, G. Secure energy supply in 2025: Indonesia's need for an energy policy strategy. Energy Policy 2013, 61, 31-41. [CrossRef]

6. Peraturan Presiden Republik Indonesia Nomor 22 Tahun 2017. In Rencana Umum Energi Nasional. 13 Maret 2017. Lembaran Negara Republik Indonesia Tahun 2017 Nomor 43; Peraturan Presiden Republik Indonesia: Jakarta, Indonesia, 2017. (In Indonesian)

7. Rosenberg, D.M.; Bodaly, R.A.; Usher, P.J. Environmental and social impacts of large scale hydroelectric change. Glob. Environ. Change 1995, 5, 127-148. [CrossRef]

8. Zhijia, G.; Xingwu, D.; Bing, L.; Jinming, H.; Jiaonan, H. The spatial distribution and temporal variation of rainfall erosivity in the Yunnan Plateau, Southwest China: 1960-2012. Catena 2016, 145, 291-300. [CrossRef]

9. Zheng, H.; Miao, C.; Wu, J.; Lei, X.; Liao, W.; Li, H. Temporan and spatial variations in water discharge and sediment load on the Loess Plateau, China: A high study. Sci. Total Environ. 2019, 666, 875-886. [CrossRef]

10. Wang, D.; Wang, X.; Huang, Y.; Zhang, X.; Zhang, W.; Xin, Y.; Qu, M.; Cao, Z. Impact analysis of small hydropower construction on river connectivity on the upper reaches of the great rivers in the Tibetan Plateu. Glob. Ecol. Conserv. 2021, 26, e01496. [CrossRef]

11. Egre, D.; Milewski, J.C. The diversity of hydropower projects. Energy Policy 2002, 30, 1225-1230. [CrossRef] 
12. Bracken, L.J.; Bulkeley, H.A.; Maynard, C.M. Micro hydropower in the UK: The role of communities in an emerging energy resources. Energy Policy 2014, 68, 92-101. [CrossRef]

13. Sato, T.; Ide, J. Sustainability of micro hydropower generation in a traditional community of Indonesia. In Decision Science fo Future Earth; Springer: Singapore, 2021; pp. 105-117.

14. Purwanto, W.W.; Afifah, N. Assessing the impact of the socioeconomic factors on sustainability indicators of microhydro power projects in Indonesia: A comparative study. Renew. Energy 2016, 93, 312-322. [CrossRef]

15. EBTKE Direktorat Jenderal. Matriks Laporan Survey Pembangunan PLTMH 2011-2016. Kementerian Energi dan Sumber Daya Mineral; EBTKE Direktorat Jenderal: Jakarta, Indonesia, 2018. (In Indonesian)

16. Bhattacharyya, S.C. Review of alternative methodologies for analysing off-grid electricity supply. Renew. Sustain. Energy Rev. 2012, 16, 677-694. [CrossRef]

17. Energising Development (EnDev) Indonesia. Survey on Key Performance Indicators for Indonesia Micro Hydro Power; GIZ: Jakarta, Indonesia, 2012.

18. Ranzanici, A. Sustainability Comparison between EnDev and Non EnDev Micro Hydro Power in Indonesia; Universidad Politecnica de Madrid: Madrid, Spain, 2013.

19. United Nations. United Nations Division for Sustainable Development. Expert Group Meeting on Indicators of Sustainable Development; United Nations: New York, NY, USA, 2005.

20. Ilskog, E.; Kjellstrom, B. And then they lived sustainably ever after?-Assessment of rural electrification cases by means of indicators. Energy Policy 2008, 36, 2674-2684. [CrossRef]

21. Ilskog, E. Indicators for assessment of rural electrification-An approach for the comparison of apples and pears. Energy Policy 2008, 36, 2665-2673. [CrossRef]

22. Gonzalez, J.S. Sustainability Study of the San Benito Poite Solar Power Project in Belize; National Centre University: Taoyuan City, Taiwan, 2009.

23. Mennecke, B.E.; West, L.A., Jr. Geographic Information Systems in Developing Countries: Issues in Data Collection, Implementation and Management; IOWA State University: Ames, IA, USA, 2001. Available online: https://core.ac.uk/download/pdf/38936965.pdf (accessed on 10 June 2021).

24. Soemantadiredja, A. Pemimpin adat dan Pembangunan Partisipatif di Kasepuhan Ciptagelar. Skripsi; Institute Pertanian Bogor: Bogor, Indonesia, 2014. (In Indonesian)

25. World Bank. Indonesia Toward Universal Access to Clean Cooking; World Bank: Washington, DC, USA, 2013.

26. Vaccari, M.; Vitali, F.; Mazzu, A. Improved cookstove as an appropriate technology for the logone valley. Analysis of fuel and cost savings. Renew. Energy 2012, 47, 45-54. [CrossRef]

27. Peraturan Menteri Kehutanan Republik Indonesia. Permenhut, Nomor: P.60/Menhut-II/2014, Kriteria Penetapan Klasifikasi Daerah Aliran Sungai. 29 August 2014. Lembaran Negara Republik Indonesia Tahun 2014 Nomor 1266; Peraturan Menteri Kehutanan Republik Indonesia: Jakarta, Indonesia, 2014. (In Indonesian)

28. Waddell, R.; Bryce, P. Micro-hydro system for small community. Renew. Energy 1990, 16, 1257-1261. [CrossRef]

29. IAEA. Energy Indicators for Sustainable Development: Guidelines and Methodologies; International Atomic Energy Agency: Vienna, Austria, 2005.

30. Sukma, M.A. Kualitas Konsumsi dan Ketahanan Pangan Serta Food Coping Strategy Pada Masyarakat Adat Kasepuhan Ciptagelar. Skripsi; Institut Pertanian Bogor: Bogor, Indonesia, 2014.

31. GIZ. Best Practice Guidline Off Grid Micro Hydro Power Schemes for Rural Electrification; GIZ: Jakarta, Indonesia, 2011.

32. Harvey, A.; Brown, A.; Hettiarachi, P.; Inversin, A. Micro-Hydro Design Manual-A Guide to Small Scale Waterpower Shemes; Intermediate Technology Publication: London, UK, 1993.

33. Murni, S.; Whale, J.; Urmee, T.; Darvis, J.K.; Harries, D. The role of micro hydro power systems in remote rural electrification: A case study in the Bawan Valley, Borneo. Procedia Eng. 2012, 49, 189-196. [CrossRef]

34. Drinkwaard, W.; Kirkels, A.; Romijn, H. A learning-based approach to understanding success in rural electrification: Insights from Micro hydro projects in Bolivia. Energy Sustain. Dev. 2010, 14, 232-237. [CrossRef]

35. Rahman, M.M.; Paatero, J.V.; Poudyal, A.; Lahdelma, R. Driving and hindering factors for rural electrification in developing countries: Lessons from Bangladesh. Energy Policy 2013, 61, 840-851. [CrossRef]

36. Gollwitzer, L.; Ockwell, D.; Muok, B.; Ely, A.; Ahlborg, H. Rethinking the sustainability and institutional governance of electricity access and mini-grids: Electricity as a common pool resource. Energy Res. Soc. Sci. 2018, 39, 152-161. [CrossRef] 